\title{
PERAN PEMERINTAH SULAWESI UTARA DALAM MENANGGULANGI TRAFFICKING ANAK
}

\author{
Septian Utut Sugiatno \\ IAIN Pontianak \\ Email: tianseptianbb@yahoo.co.id
}

$\begin{array}{ll}\text { Judul Buku } & : \text { Trafficking Perempuan dan Anak (Penanggulangan } \\ & \text { Komprehensif Studi Kasus: Sulawesi Utara) } \\ \text { Editor } & : \text { L.M. Gandhi Lapian \& Hetty A. Geru } \\ \text { Penerbit } & : \text { Yayasan Obor Indonesia } \\ \text { Tebal } & : \text { 274 Halaman }\end{array}$

Perubahan atas Undang-Undang Dasar Republik Indonesia Nomor 23 Tahun 2002 ke Undang-Undang Dasar Republik Indonesia Nomor 35 Tahun 2014 tentang Perlindungan Anak sedikit banyak memberi harapan kepada anak-anak Indonesia dalam mendapat hak-hak positif demi kehidupan yang cerah di masa akan datang. Hal tersebut tertuang di Pasal 21 Ayat 1 bahwa Negara, Pemerintah, dan Pemerintah Daerah berkewajiban dan bertanggungjawab menghormati pemenuhan Hak Anak tanpa membedakan suku, agama, ras, golongan, jenis kelamin, etnik, budaya dan bahasa, status hukum, urutan kelahiran, dan kondisi fisik dan/atau mental. Selanjutnya Pasal 21 Ayat 2 menyatakan untuk menjamin pemenuhan Hak Anak sebagaimana dimaksud pada ayat (1), negara berkewajiban memenuhi, melindungi, dan menghormati Hak Anak. Kemudian pada Ayat 3 menjelaskan bahwa untuk menjamin pemenuhan Hak Anak sebagaimana dimaksud pada ayat (1), Pemerintah berkewajiban dan bertanggung jawab dalam merumuskan dan melaksanakan kebijakan di bidang penyelenggaraan Perlindungan Anak.

Secara garis besar perubahan mencolok Undang-Undang Dasar Republik Indonesia Nomor 23 Tahun 2002 ke Undang-Undang Dasar Republik Indonesia Nomor 35 Tahun 2014 tentang Perlindungan Anak terletak pada keterlibatan aktif pemerintah daerah untuk memberikan sarana maupun prasarana dan perlindungan, pemeliharaan, dan kesejahteraan anak. Hal itu tercantum dalam Pasal 22 bahwa Negara, Pemerintah, dan Pemerintah Daerah berkewajiban dan bertanggungjawab memberikan dukungan sarana, prasarana, dan ketersediaan sumber daya manusia dalam penyelenggaraan Perlindungan Anak. Selanjutnya pada Pasal 23 Ayat 1 dan 2 menjelaskan bahwa Negara, Pemerintah, dan Pemerintah Daerah menjamin perlindungan, pemeliharaan, dan kesejahteraan Anak dengan memperhatikan hak dan kewajiban Orang Tua, Wali, atau orang lain yang secara hukum bertanggungjawab terhadap Anak. Negara, Pemerintah, dan Pemerintah Daerah mengawasi penyelenggaraan Perlindungan Anak.

Peraturan tetaplah peraturan. Namun faktanya, kasus trafficking terhadap anak masih merajalela di Indonesia. (L.M. Gandhi Lapian \& Hetty A. Geru (ed.), hlm. 58). Fakta menunjukkan bahwa dalam masyarakat dunia termasuk Indonesia masih terjadi tindakan serupa perbudakan dan tindakan trafiking manusia terutama perempuan dan anak. Data trafiking perempuan dan anak malahan menunjukkan tren yang meningkat seiring dengan peningkatan sarana transportasi, kecanggihan sarana elektronik, globalisasi, kalahnya hati nurani terhadap keuntungan financial komersialisasi, dan sebagainya. 
Suatu studi tentang trafficking manusia dengan tujuan prostitusi mengungkapkan bahwa cukup besar jumlah anak yang dipaksa bekerja dalam prostitusi. Perwakilan NGO UN CRC menyatakan bahwa 30\% dari mereka yang dipaksa bekerja dalam prostitusi anak. Dalam tahun 1998 UNICEF memperkirakan prostitusi anak di Indonesia berkisar antara 40.000-70.000 anak. Permintaan akan anak-anak untuk prostitusi diperkirakan makin meningkat karena asumsi bahwa anak-anak lebih kurang risikonya terhadap terinfeksi STDs dan HIV/AIDS.

Adapun kasus trafficking di Sulawesi Utara khususnya pada anak berdasarkan Laporan Pusat Studi Wanita Unsrat dalam penelitian tentang Kesejahteraan dan Perlindungan Anak (KPA) menemukan bahwa banyak anak di bawah umur (40\%) yang bekerja pada bar, restoran pada pub di kota Manado. Angka ini lebih tinggi dari angka Nasional yang hanya 30\%. Belum diperoleh informasi apakah anak-anak ini dilacurkan atau melacurkan diri (atas kemauan sendiri). Bagi anak di bawah umur (18 tahun), tidak ada tuduhan melacurkan diri, pasti ada yang mengajak. Hasil penelitian Pusat Studi Wanita bahwa di samping umurnya di bawah 18 tahun, juga ada yang dengan kesadaran sendiri menjadi teman minum laki-laki di pub/cafe, (Just for fun). Berdasarkan hasil penelitian Pusat Studi Wanita Universitas Sam Ratulangi (tentang Kesejahteraan dan Perlindungan Anak) mengemukakan bahwa ada di antara anak-anak gadis (yang bekerja di Pub dan Restoran sepanjang Boulevard Manado), masih duduk di bangku SLTA atau mahasiswa dan mereka mengemukakan bahwa mereka hanya ingin mencari kesenangan (for fun), bukan alasan mencari tambahan biaya sekolah. Hal ini dapat dikaitkan dengan ungkapan-ungkapan yang sering dikemukakan oleh orang Sulawesi Utara seperti 'biar kalah nasi asal jang kalah aksi' (meskipun kalah nasi tapi jangan kalah aksi).

Kasus-kasus trafficking yang terjadi di Sulawesi Utara, beberapa telah ditangani oleh pihak terkait, di antaranya: kasus menjadi pelayan bar dan restoran, kasus pengiriman penari ke Jepang dengan Visa Entertainment, kasus Eksploitasi Seksual Komersial Anak (ESKA), kasus-kasus yang ditangani oleh RPK Polda Sulut, Polresta Manado dan Pusat Informasi dan Perlindungan Perempuan dan Anak (PIPPA-BKOW), evakuasi kasus dari Kapal Penginjilan K.M. Hannah II, kasus 23 anak dari bar di Timika, kasus Mangole, kasus perdagangan bayi.

Adapun upaya-upaya pemerintah daerah melalui pihak-pihak terkait kaitannya tentang penanggulangan trafficking yang ada di Sulawesi Utara di antaranya: penerbitan dan pemberlakuan Perda No. 1 Tahun 2004 tentang Pencegahan dan Pemberantasan Perdagangan Manusia (Trafficking), pelaksanaan Konferensi Daerah Pencegahan dan Pemberantasan Trafficking Perempuan dan Anak yang menghasilkan Rencana Aksi Daerah 2004-2007, pembentukan Satuan Tugas Anti Trafiking Perempuan dan Anak di Provinsi Sulut, penanganan kasus trafiking melalui Shelter (Rumah Aman) TP PKK Sulut dan PIPPA (Pusat Informasi dan Perlindungan Perempuan dan Anak) asuhan BKOW Sulut, pembentukan jaringan anti trafiking, pelatihan pendampingan korban kekerasan terhadap perempuan dan anak kerjasama Biro PP, TP PKK, dan BKOW dan pesertanya membentuk Jaringan Tamang Anak dengan Perampuang - J.TAP), Pelatihan Hakim (Mahkamah Agung), Pelatihan Jaksa dan Penegak Hukum (Convention Watch UI), pemberdayaan Komunitas Lokal oleh LSM peduli gender (Suara Perampuang, PKBI, Yayasan PEKA, Yayasan Sofia), Convention Watch, TP PKK Sulut di semua tingkatan.

Namun begitu dari sekian banyak kasus yang telah ditangani maupun diupayakan pemerintah daerah, ada beberapa kasus yang diduga belum ditindaklanjuti karena terkendala dana. Di antaranya: dugaan kasus trafiking di Kendari, kasus trafficking di Samarinda, dan kasus Timika II. Menurut hemat penulis, ketika berbicara mengenai hak anak yang seharusnya memiliki 
kehidupan yang layak dan baik secara fisik dan mental, dana bukanlah sesuatu yang memberatkan. Di sinilah peran pemerintah pusat dan daerah sebagai ujung tombak negara. Hak anak adalah kewajiban pemerintah pusat dan daerah, terlebih lagi kewajiban juga bagi orang tua sebagai penopang keluarga. Namun esensinya hak anak adalah kewajiban kita semua, karena anak merupakan aset bangsa yang nantinya akan membawa negeri ini semakin maju dan berdaya saing di dunia global.

Bagi penulis, buku ini sangat informatif dan cocok untuk dibaca oleh aktifis sosial yang fokus bergerak dalam bidang serupa, karena dengan banyaknya informasi terkait trafiking anak akan semakin memperluas wawasan dan memberikan tawaran langkah solutif bagi pemerintah pusat dan daerah untuk mencegah terjadinya hal serupa. 